\title{
Strategic Ambidexterity Learning of Innovation Activities: A Study of Indonesian Business Group Leader
}

\author{
Retno Kusumastuti ${ }^{1}$ \\ Azhar Kasim ${ }^{2}$ \\ Sudarsono Hardjosoekarto ${ }^{3}$
}

\begin{abstract}
Competitive advantage refers to the attributes an organization maintains to better perform in comparison to its competitors. According to the Resource Based View, human capital has become a source of competitive advantage. Literatures exploring how strategic leadership leads to ambidexterity practice is still very rare. Ambidexterity practices is about how organizations learn to conduct innovation activities in both exploitative and explorative manner. A prominent leader should have influence on innovation activities in their organization through the decisions they have made. This study analyzed how a corporation had implemented ambidexterity learning practices to create competitive advantage based on the leader's cognitive map. A leader's cognitive map is a mental construct that represents the way the leader thinks in order to deal with the prevailing environment. The dynamics of the cognitive leader is portrayed by conversing the entrepreneur's cognitive map using the Normalized Unit Modeling by Elementary Relationship (NUMBER). This research was conducted with Lippo Karawaci (LPKR) serving as the object of study. LPKR's success is without a doubt inseparable from the role of its leader. The results of this research show that learning process and ongoing participation based on culture to pursue competitive advantage in ambidexterity practices had occurred in LPKR. Furthermore, this study shows the importance of strategic orientation in ambidexterity learning process through proper management of the company's resources. The identified strategic directions-human resource, technology, profitability, and entrepreneurship - may be considered as sources of competitive advantage. This research is of significant value as it presents how a big corporation, such as LPKR, constantly creates new opportunities through exploratory and exploitative innovations and learning process simultaneously thereby becoming an ambidextrous organization.
\end{abstract}

\section{Keywords:}

cognitive map (CM); resource-based view (RBV); system dynamics (SD); ambidexterity learning process.

\footnotetext{
${ }^{1}$ Faculty of Administrative Science, Universitas Indonesia

Email: r.kusumastuti@ui.ac.id

${ }^{2}$ Faculty of Administrative Science, Universitas Indonesia

Email: akasim2@yahoo.com

${ }^{3}$ Faculty of Social and Political Sciences, Universitas Indonesia

Email: sudarsono.h@ui.ac.id
} 


\section{Introduction}

Creation of value in the future will likely depend on the ability and motivation of organization leaders in creating innovations (Jakarta Stock Exchange, 2006). The role of a leader is, therefore, most vital in defining the vision and mission of the organization. Successful companies require leaders possessing superior entrepreneurial attitude. An entrepreneurial-oriented company is a company that has the ability to perform activities in search of new opportunities to create innovative product breakthroughs. Such activities are known as explorative innovations (Situngkir, 2004, p. 109).

A company is basically an organic business entity operated by people that serves as a key element in determining the success or failure of the business. A company experiences a process of birth, aging, illness, and death reflected through three stages (Kusumastuti et al., 2016). Lippo Karawaci (LPKR) is one of the business groups that has managed to grow and thrive, even survive through the third generation. As noted by Wall Street Journal in 1994, the business group had a very rapid business expansion with its deployment territory from Hong Kong, China - Shanghai, Singapore, Thailand, the Philippines, Taiwan, Malaysia, and Indonesia as the basis of the domestic business group that started its business in 1976 (Kusumastuti et al., 2015). The founder and chairman of the Lippo Group is Mochtar Riady who was born in May of 1929 in Malang, East Java. He graduated from the Southeast University in 1949 and has a Honorary Doctor of Laws from Golden Gate University, San Francisco, he is also known as a reliable employer.

Various existing resources in companies are developed to create exploitative innovations; nevertheless, it can also be achieved by seeking possibilities for new opportunities through exploration. One of the resources considered to be of strategic significance is human resource.
Hence, any kind of efforts to enhance human resource capacity becomes an integrated part of every innovation made in the learning process to produce competitive companies in the current era of globalization.

"Being large and successful at one point in time is no guarantee of continued survival." The potential for structural and cultural inertia becoming obstacles in anticipating changes in the existing environment increases along with the company's growth and development (Situngkir, 2004). As stated by Smith (Perusich, 2010), the development of a company is affected by the capabilities of its leader or leadership in confronting turbulent environmental changes. Thus, it is crucial to explore the founder of the company's understanding on achieving competitive advantage. The objective of this research is to analyze the framework of the founder and owner in formulating the corporation's competitive advantage.

The formulation of competitive advantage will be illustrated in a cognitive map.

\section{Theoretical Framework}

A company is said to possess competitive advantage when "the advantage cannot be imitated by other companies". This is of course based on the assumption that the company's resources are heterogeneous and stationary (LPKR Annual Report, 2011). The relation between all the resources within an organization as a source to generate competitive advantage is depicted in Figure 1.

According to Barney and Clark (LPKR Annual Report, 2011) there are a number of components within the organization that affect this process, including: the formal organizational structure, management control systems, and employee compensation policies. These three components are often referred to as complementary resources and capabilities. From a resource-based view, organizational capability can be considered as a source of competitive advantage (LPKR Annual Report, 
Figure 1.

Company Resources and Competitive Advantage.

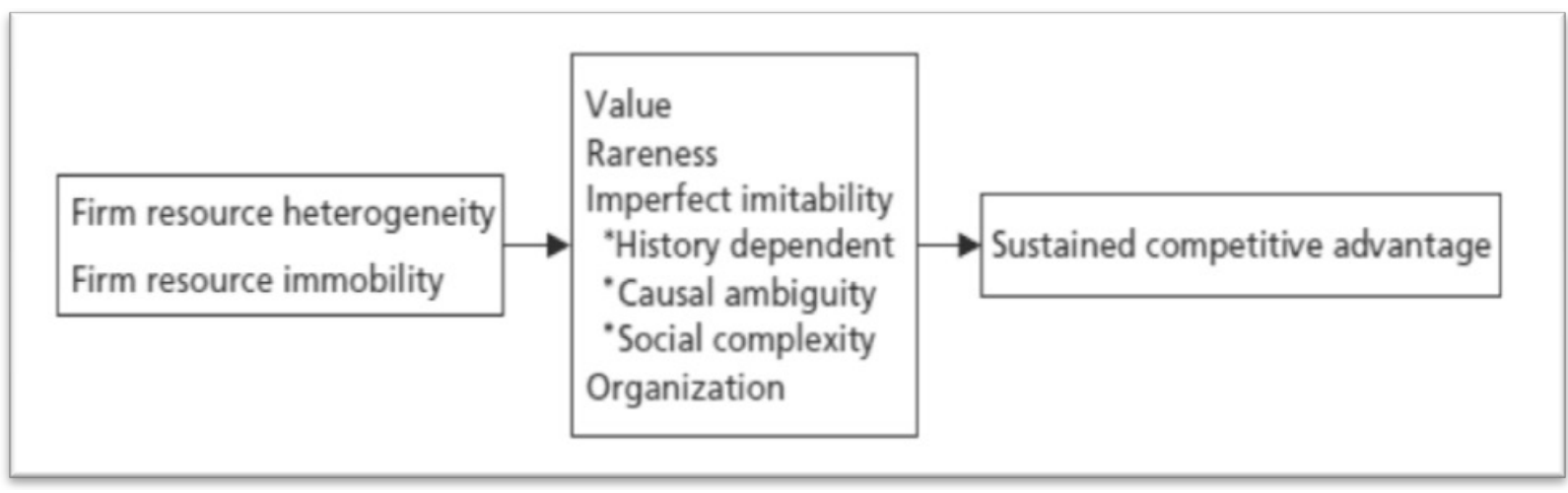

Source: Jay Barney and Delwyn Clark (LPKR Annual Report, 2011)

Table 1.

\section{Guideline to Evaluate Company's Resources} Evaluation of Company's Resources

\begin{tabular}{|c|c|}
\hline \multicolumn{2}{|r|}{ Tangible Resources } \\
\hline Financial & $\begin{array}{l}\text { a. Firm's cash and cash equivalents } \\
\text { b. Firm's capacity to raise equity } \\
\text { c. Firm's borrowing capacity }\end{array}$ \\
\hline Physical & $\begin{array}{l}\text { a. Modern plant and facilities } \\
\text { b. Favorable manufacturing locations } \\
\text { c. State-of-the-art machinery and equipment }\end{array}$ \\
\hline Technological & $\begin{array}{l}\text { a. Trade secrets } \\
\text { b. Innovative production process, patents, copyrights, trademarks }\end{array}$ \\
\hline Organizational & $\begin{array}{l}\text { a. Effective strategic planning process } \\
\text { b. Excellent evaluation and control systems }\end{array}$ \\
\hline \multicolumn{2}{|r|}{$\begin{array}{c}\text { Intangible Resources } \\
\end{array}$} \\
\hline Human & $\begin{array}{l}\text { a. Experience and capabilities of employees } \\
\text { b. Trust } \\
\text { c. Managerial skills } \\
\text { d. Firm-specific practices and procedures }\end{array}$ \\
\hline Innovation and Creativity & $\begin{array}{l}\text { a. Technical and scientific skills } \\
\text { b. Innovation capacities }\end{array}$ \\
\hline Reputation & $\begin{array}{l}\text { a. Brand name } \\
\text { b. Reputation with customers for quality and reliability } \\
\text { c. Reputation with suppliers for fairness, non-zero-sum relationships }\end{array}$ \\
\hline \multicolumn{2}{|c|}{ Organizational Capabilities } \\
\hline \multicolumn{2}{|c|}{$\begin{array}{l}\text { a. Firm competences or skills the firm employs to transfer inputs to outputs } \\
\text { b. Capacity to combine tangible and intangible resources, using firm processes to attain desired end. } \\
\text { Examples }\end{array}$} \\
\hline \multicolumn{2}{|c|}{$\begin{array}{ll}\text { a. Outstanding customer service } & \text { a. Innovativeness or products and services } \\
\text { b. Excellent product development capabilities } & \text { b. Ability to hire, motivate, and retain human }\end{array}$} \\
\hline
\end{tabular}

Source: Jay Barney and Delwyn Clark (LPKR Annual Report, 2011).

2011). Sources of competitive advantages include: culture, trust, human resource and information technology.

Table 1. shows a guideline to evaluate company's resources by using the framework of Barney and Clark (LPKR Annual Report, 2011).

In relation to assets owned by a company, the study Marr, Schiuma, and Neely (Giordano and Birkinshaw, 2007) conducted complements 
previous studies. Marr et al. provide a taxonomy of organizational assets as follows: Financial resource; Physical resource; Relationship resource; Human resource; Cultural resource; Practices and Routines resource, and Property Rights resource. Empirical Research within the Resource Based Theory, published in 2008 by Nothnagel, indicates that the resource category in a company consists of tangible and intangible assets as follows: Tangible assets such as technological and financial capital, and Intangible assets such as routine, patent, reputation, brand, network, corporate culture, etc.

Alvarez \& Busenitz (2001) theoretically examined the relation between strategic management and entrepreneurship. In addition to fill existing gap in the theoretical literature, Alvarez and Busenitz's study was done to fill the void in strategic management studies in the context of entrepreneurship, since the confluence of strategic management and entrepreneurship is rarely examined by academicians such as Peteraf, (Hitt et al., 2002); Ray, Barney, Clark and Muhanna, (LPKR Annual Report, 2011). Entrepreneurship and strategic management have analysis unit of resources, both tangible and intangible assets. For Alvarez and Busenitz, entrepreneurship has four elements that indicate the unique characteristics of an entrepreneur, i.e.
Entrepreneurial Cognition, Entrepreneurial Discovery, Market Opportunities, and Coordinating Knowledge. The four elements deal with Peteraf's strategic management (Hitt et al., 2002), i.e. the heterogeneity of resources, limit of ex-post competition, mobility of imperfect factors, and limit of ex-ante competition. The conceptual model in the study of Alvarez and Busenitz (LPKR Annual Report, 2011) can be observed in Figure 2.

At present, the development of the cognitive approach in providing an understanding of how entrepreneurs think and make decisions appears to show promising results (Alvarez \& Busenitz, 2001). The most recent research trend shows an inclination toward the importance of entrepreneurial cognition, believing that businessmen as entrepreneurs intensively use a heuristic process to make decisions. Alvarez and Busenitz (Alvarez \& Busenitz, 2001) believe that lack of careful attention to the entrepreneurial cognition process, would lead to an insufficient understanding of entrepreneur.

Studies on competitive advantages are mostly developed from perspectives of resource based view. Most recent research in this subject matter aims to understand competitive advantage exploration not only from a strategic management point of view (resource based view) but also from a psychological point of

Figure 2.

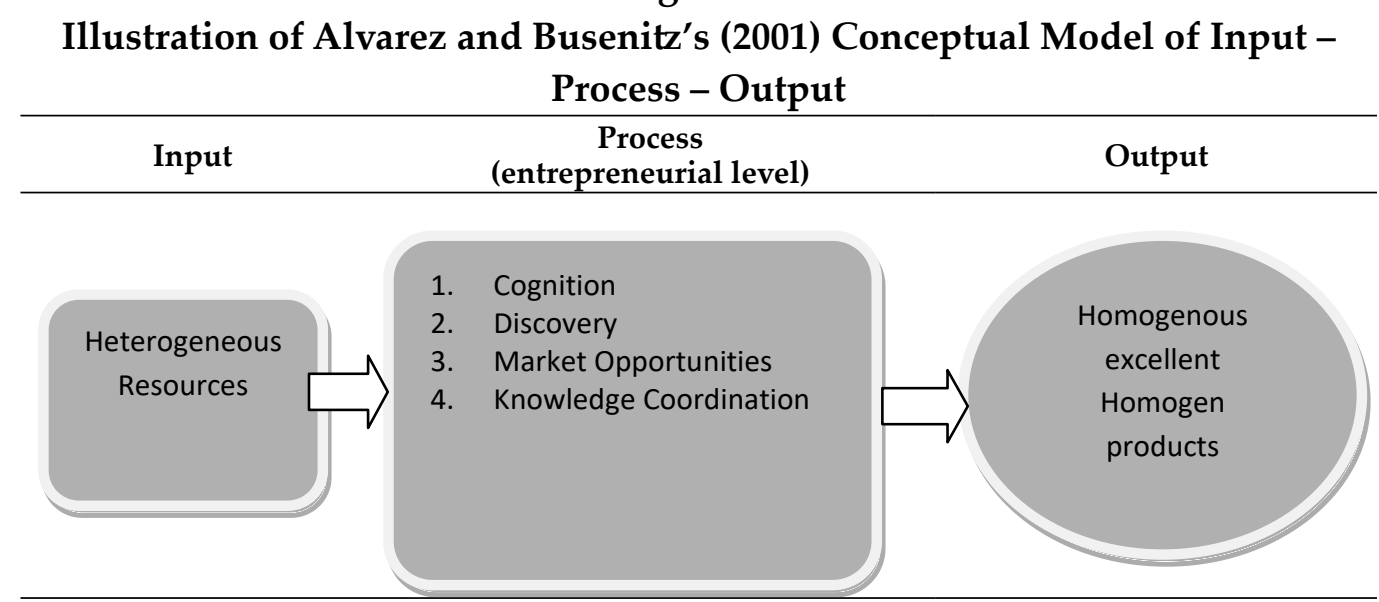

Source: Sharon Alvarez and Lowell Busenits (2001). 
view (cognitive mind of the business leader), which remains elusive. Entrepreneurial activity is a kind of explorative way and strategic management activity that focuses on an exploitative way of learning (Ulengin \& Topcu, 1997). This framework is closely related to Alvarez and Busenitz's concept which takes into account the entrepreneurial action as an input and output process (Alvarez and Busenitz, 2001). It also relates to William Hitt's proposition of considering strategic entrepreneurship as an interplay between an entrepreneurial view and a strategic management view (Riady, 2008).

\section{Methods}

Cognitive map is often referred to as influence diagrams and is used to simulate the impact of potential actions being taken on the building elements in a system (Barney \& Clark, 2007). The use of causal map illustrates the interactions between the factors taken into account in dissecting social problems. This is done by describing the relations between the various social system variables believed to have links with the dissected problems (Jensen et al., 2009). Causal maps can be used for two purposes, namely decision assessment and diagnosis (Marr, Schima \& Neely, 2004).

Based on the limitation of cognitive map stated by Kim (2000) above, a causal map is used, i.e. a scheme illustrating the interactions occurring among variables that are taken into consideration when dissecting social issues. Causal maps are, particularly, utilized as a link between systems insights and systems modeling. This is conducted by describing the relations among various social system variables believed to have correlation with the dissected issues (Situngkir, 2004, p. 109). Causal maps may be used for two purposes, namely decision assessment and systems diagnosis (Perusich, 2010).

Inquiries on the locus of a concept (variable) are of significant importance, particularly when composing a map or during its stages of composition. According to both Ackermann and Kim (2000), there is no specific definition regarding the map's most accurate form. Interview transcripts, speech documents, and other secondary sources consisting of long sentences may at times make it difficult for researchers to capture the main ideas contained within every sentence. The following guideline made by Ackermann et al. (1992) is, thus, employed in this study to facilitate in composing a cognitive map.

Stage 1: Separating sentences into distinct phrases. Mapping will be most effective when concepts (variables) are sorted based on their types, in which the idea of layers is used. The simplest layer is Goals at the very top, Strategic Directions in the middle, and Potential Options at the bottom.

Stage 2: Building hierarchy to acquire the right model structure. The goal is positioned at the top of the hierarchy, which is then supported by concepts indicating the strategic direction, and ultimately by existing potential options.

Stage 3: Defining goals, which is considered as the top of hierarchy on the map. Goals are things considered as "good" by the object. Defining goals is very helpful as it serves as the point of integration and distinction among the existing concepts. Defining goals is a superordinate concept that facilitates in writing down the other concepts.

Stage 4: Determining strategic directions. Strategic direction is a concept that has the following characteristics: long term implications, high cost, irreversible, need a portfolio of actions to make it happen, and may require change in culture. At times there is flat hierarchy among Strategy Directions, however, they always correlate with Goals and Potential Options.

Stage 5: Looking for opposite poles within concepts. This is carried out to clarify the meaning of concepts. 
Stage 6: Adding meaning to concepts by placing the concepts in the imperative form and where possible including actors and actions. By conducting this measure, the structure becomes more dynamic.

Stage 7: Retaining ownership by not abbreviating but rather keeping the words and phrases of the study object. If necessary, the owner of the concept may be incorporated.

Stage 8: Identifying the option and outcome within each pair of concepts. A viable means is by putting arrow pointers linking one concept to another. Determine concepts that are included as "means" and those included as "desired ends". Each concept can be seen as an option leading to its superordinate concept which in turn is the desired outcome of the subordinate concept.

Stage 9: Ensuring that a generic concept is superordinate to the specific items that contribute to it. Generic concepts are indicated as those for which there are more than one specific means of achieving it.

Stage 10: Coding the primary idea of the study object. This is done by paying attention to the initial pole of the first sentence made by the object. This point serves as the initial point in reading the entire map. Consequently, the links produced with other concepts may be positive although it would be possible to change it into negative.

Stage 11: Tidying up. This action needs to be carried out in order to have a better understanding of the map drawn and to ensure the why certain concepts are isolated and not linked in to other parts.

The techniques employed in building a cognitive map were in-depth interviews, coding of documents, questionnaire, and surveys (Peteraf, 1993). In-depth interviews were conducted with the founders, managers, and owners of the corporate group, as well as with the President Director and members of the Board of Directors and the Board of Commissioners. The preparation of cognitive map used the guidelines formulated by Ackerman et al. (Alvarez \& Busenitz, 2001).

Subsequently, an abstract simulation method was applied to explore the dynamic side of the cognitive and causal map with reference to Kim (East Asia Analytical Unit, 1995). The abstract simulation method proposed by Kim is known as the NUMBER method (Normal Unit Modeling by Elementary Relationship). There are three (3) stages in the NUMBER method, namely:

1. Based on the role of the variables in the causal map, the researchers selected ninelevel-variables/stock-variables with the consideration that these variables are those considered most important by the problem owner.

2. The value of each variable was normalized in the closed interval $[0,1]$. That is why this method is referred to as a Normalized Unit Modeling. Each variable has the possibility of having a different scale. Normalization of the variables was necessary in order to make all variables comparable (the formula of variable-transformation that can be used to normalize the variable-value can be seen in the Annex).

3. The variables in the map are connected by Elementary Relationships, designed to limit the variable-value in the closed interval [0,1]. In particular, level-variables are associated with rate-variables that are automatically generated by the relationship previously defined. That is why this method is called the Elementary Relationships.

\section{Results and Discussion}

\section{Strategic Directions}

Riady possesses four strategic directions, i.e. Human Capital Strategic Direction, Technology Resources Strategic Direction, Financial Resources Strategic Direction, and Entrepreneurship Strategic Direction. Furthermore, Figure 3 presents Riady's causal map. 
Figure 3.

Riady's Causal Map

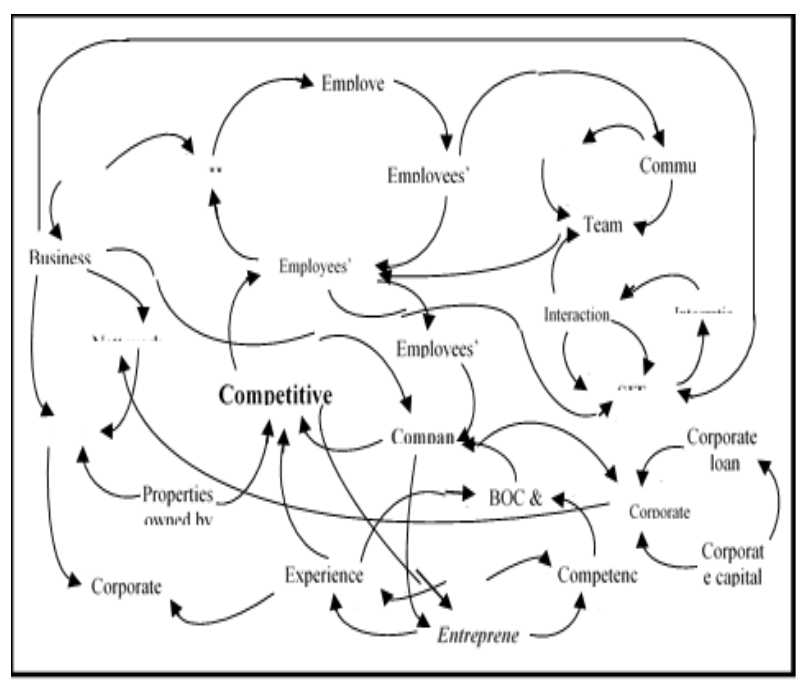

Source: processed data (2012)

1. Human Resource Strategic Direction

Riady's understanding on the strategic direction of Human Capital is divided into two levels, namely: the employee level and the top management level. This strategic direction has led to the creation of a Human Resource pool containing the expertise and competence required by the company and bearing unique characteristics of being creative, loyal, true believer, and spiritually enriched. In addition, LPKR has an experienced and competent line of Top Management Executives. Appropriate human resource management can, thus, contribute potential added values to the company.

Based on the mapping results of the existing composition of human resources in 2011 from Ramachandran (Investor Summit and Capital Market Expo, 2011), it is shown that a large portion of their employees had a high school background. This prompted the company to implement a new recruitment policy of having a minimum education level of bachelor's degree in the following year so that the education-based composition of human resources becomes more balanced. To support the next potential option, namely Recruitment, information about the employment vacancy is then listed openly on the company's website so that it can be widely disseminated to the public.

Assessment concerning the quality of human resources undoubtedly affected the following potential option, namely the Education and Training programs held by the company. Commitment to employee capacity building is reflected in the implementation of various programs of sustainable human resource development at every level. Year 2011 data shows the number of participants who attended training, based on the group's respective industry: the shopping centers had trained as many as 565 participants; the housing complex as many as 99 participants; the company groups as many as 122 participants; hospitality as many as 147 participants; and hospitals as many as 89 participants. Meanwhile in 2012, the number of employees who participated in training and development programs totaled 450 people solely for leadership/managerial positions of all business lines (Wijaya, interview result on July 25, 2012, from 11:00 to 12:00 pm, LPKR)

The subsequent step is implementing proper Performance Management System to ensure that the compensation applied is based on meritocracy, so that the company can further streamline the salary structure of employees as assigned by their job evaluation and analysis (Riady, 2008).

The following potential option considered necessary is establishing Openness in Communication. Openness in communication is regularly conducted to express all the problems occurring at every managerial level either formally or informally. Routine meetings are usually conducted on a weekly basis per division and depending on the needs of each division. At a higher level, regular meetings occur more frequently for example: the General Meeting of Shareholders, the Board of Directors Meeting and Board of Commissioners Meeting.

The next potential option is creating a Conducive Work Environment. This is in line 
with Jensen et al. wherein the organizational climate is a psychological condition of the organization with regard to all members of the organization both leaders and subordinates (Smith \& Tushman, 2005). LPKR showed working conditions in which psychological pressure is low. On the other hand, however, the enthusiasm of organization members with the desire to change (adjust to existing customs) and seek something new is quite high. In the concept proposed by Jensen et al., these conditions are included in the category of Developmental Climate. In such a setting, generally everyone feels comfortable working; there is trust among the members; conflict is very rare and reward is seen as something fairly given.

\section{Technology Resource Strategic Direction}

Information Technology (IT) resources include all the systems and processes that support employee management as a key unit of an organization. IT has changed the process of human resource management by improving human resources productivity, competitiveness enhancement, expansion of employees' experience, and maximization of employees' value by aligning their skills, activities, and benefits to the business goals and corporate strategy.

In terms of the strategy employed to maximize the support of information technology systems for improving organizational capacity, Riady deems it necessary to apply technology in each of the company's business lines in an effort to anticipate the development of information technology and globalization. In the span of the last 10 years, LPKR has begun to run the Oracle system in 2008, mainly for financial procedures. In the following year, in 2009, various operational applications began to be implemented in the form of local applications such as arrangement of leave permits, vacation permits, etc. Each employee can easily obtain the paycheck of their salary. Moreover, they can also submit individual performanceassessment to their superiors online. The following year, in 2010, self-service began to be implemented, such as when applying for medical treatment. The founder's attention to the urgency of strategic direction in the field of information technology is reflected in his book entitled "Searching for Opportunities amidst Crisis", released when Indonesia was facing financial crisis in 1998-1999.

\section{Financial Resource Strategic Direction}

Corporate leaders have always been quick in preparing all of their business units to go public. The initial public stock offer had made the Jakarta Stock Exchange widely known to the world and demanded by foreign investors (Kim, 2000). LPKR undertook significant business reorganization in 2004 through the merger of eight property companies under the management of Lippo. From the aspect of financial resources, the company is the largest property company in Indonesia with a revenue of 1.9 trillion rupiah $(1 \mathrm{H} 2011)$ and a market capitalization of 1.7 billion USD (East Asia Analytical Unit, 1995).

LPKR is known as a leader in the development of urban and residential areas, hospitals and retail malls, but it is also noted as the only national property company rated by international rating agencies (Standard \& Poor's: B +, Moody's: B1, Fitch: B +). In terms of financial resources, LPKR forms the most integrated business models with the ability to recycle capital. The capitalization of Lippo Karawaci is top ranked (second largest) reaching 2.094 billion USD, only one rank below Bumi Serpong Damai which sits at 2.178 billion USD.

The most optimal composition of capital structure for the company was estimated to range between the ratio of 60:40. Its breakthrough was by being the first company from Southeast Asia to publish Real Estate Investment Trusts (REIT) and it was recorded 
at the Singapore Stock Exchange. The issuance of the REIT was to restructure the company's assets by maximizing the revenue of certain company's assets and leveraging the moment of investment for foreign investors. This moment was noted during the Jakarta Stock Exchange announcement on Wednesday, August 16, 2006 (Scheer, 2009).

\section{Entrepreneur as a Business Leader Strategic Direction}

Riady's vision is associated with his entrepreneurial spirit, inspired by his childhood experience. This is consistent with the philosophy of Lao Tzu, i.e. "all there is comes from nothing" and "a tree as wide as a man's embrace springs from a small shoot" that he upholds as his life philosophy. He internalizes these values; then gradually and consciously applies them in his business. Sato noted that the business group is among one of those that grew during the period of the Oil Boom in 1981.

The course and development of the post oil boom period (1974 to 1981), precisely in 1986, had put the business group to reach estimated total sales of more than 200 billion USD, by which the company had developed into 35 business units (Kusumastuti et al., 2015). As a business group owned by ethnic Chinese, its development goes hand in hand with extended-family business, through the link of marriages of the Taipan's sons and daughters. The illustration below depicts the crossshareholdings and family linkage $=$ family connection $=\mathrm{F} / \mathrm{C}$ based on a survey conducted by the Department of Foreign Affairs and Trade of Australia (Barney \& Clark, 2007).

As an entrepreneur and business leader, Riady's most prominent activities are to coordinate and motivate. These are reflected in the potential option to formally and informally interact with managers, be it with the President Directors, Board of Directors, or Board of Commissioners. This activity is crucial for achieving convergence of business conception between the company's owner and founder and its managers, in order to reduce any potential agency problem (Kusumastuti, 2017).

Conveying his business conception to the top management team in the corporation is a kind of contextual ambidexterity learning which the founder has provided sufficient space for top management to innovate in an explorative manner. This form of innovation learning activities is similar to the results of a previous research done by Kusumastuti et al. The research shows that such innovation learning process was found to occur in Small Medium Enterprises, wherein the founder playing the role of owner and manager also provides employees with abundant space to innovate through his trust and support. This form of learning process to innovate is called contextual ambidexterity learning (Smith \& Tushman, 2005).

In the context of universities, the process of innovative learning to become a world class research university occurs in two forms, namely structural ambidexterity and contextual

Figure 4.

\section{A Model of Riady's System Dynamics}

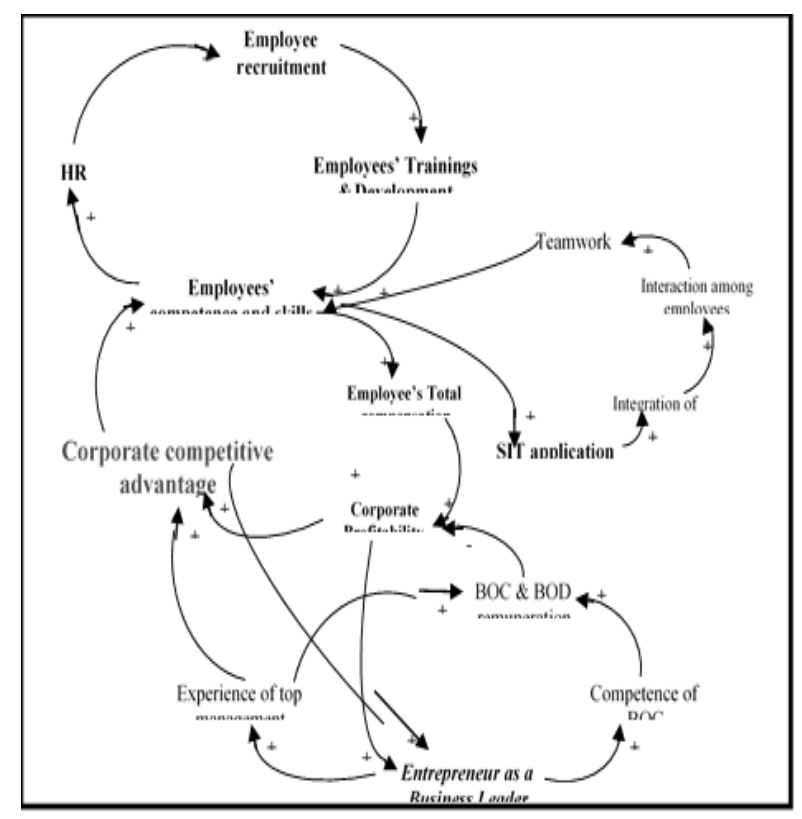

Source: processed data (2012) 
ambidexterity learning process. Structural ambidexterity refers to the existence of a separate and different unit, along with different competence, system, incentive, process, and culture which will internally be aligned and adjusted for the purpose of exploration and exploitation (Ulengin and Topcu, 1997). Whereas in Small and Medium Enterprises, the contextual ambidexterity learning of innovation activities are more likely to occur [29].

\section{Competitiveness of the Company}

The conversion of the causal map, as shown in Figure 4, into a model of system dynamics, can use the NUMBER method. Based on Riady's causal map, six feedback loops were observed. Upon analysis of the loops, nine level variables were obtained as shown in Figure 5.

The rate variable is established by those associated with the level variable (both level and non-level variables). Level variable, also known as stock variable, is an accumulated variable and can be depleted over time (to zero). Figure 6 shows the results of the conversion of Riady's causal map by using the NUMBER Method to obtain a model of system dynamics.

\section{System Dynamics Model by Using the NUMBER Method}

The NUMBER method can be employed to convert the causal map presented in Figure 5 into a system dynamics model as shown in Figure 6. Based on Riady's causal map, there are six feedback loops observed. Upon analysis of the loops, nine level variables were obtained as shown in Table 2.

Meanwhile, the rate variable is established by variables associated to the level variables (both level variables and non-level variables).

Level variable, also known as stock variable, is an accumulated variable that can be depleted

Table 2.

Nine Level Variables

\begin{tabular}{cl}
\hline No & \multicolumn{1}{c}{ Variable Names } \\
\hline 1 & Human Resource \\
2 & Recruitment of Employees \\
3 & Employee Training and Development \\
4 & Employee Competence and Skills \\
5 & Total Compensation of Employees \\
6 & Company Profitability \\
7 & Company's Competitiveness Advantage \\
8 & Application of IT System \\
9 & Entrepreneur as a Business Leader \\
\hline
\end{tabular}

Source: research result (2012)

Figure 5.

\section{Conversion Result of Riady's Causal Map using the NUMBER Method to Obtain a Model of System Dynamics}

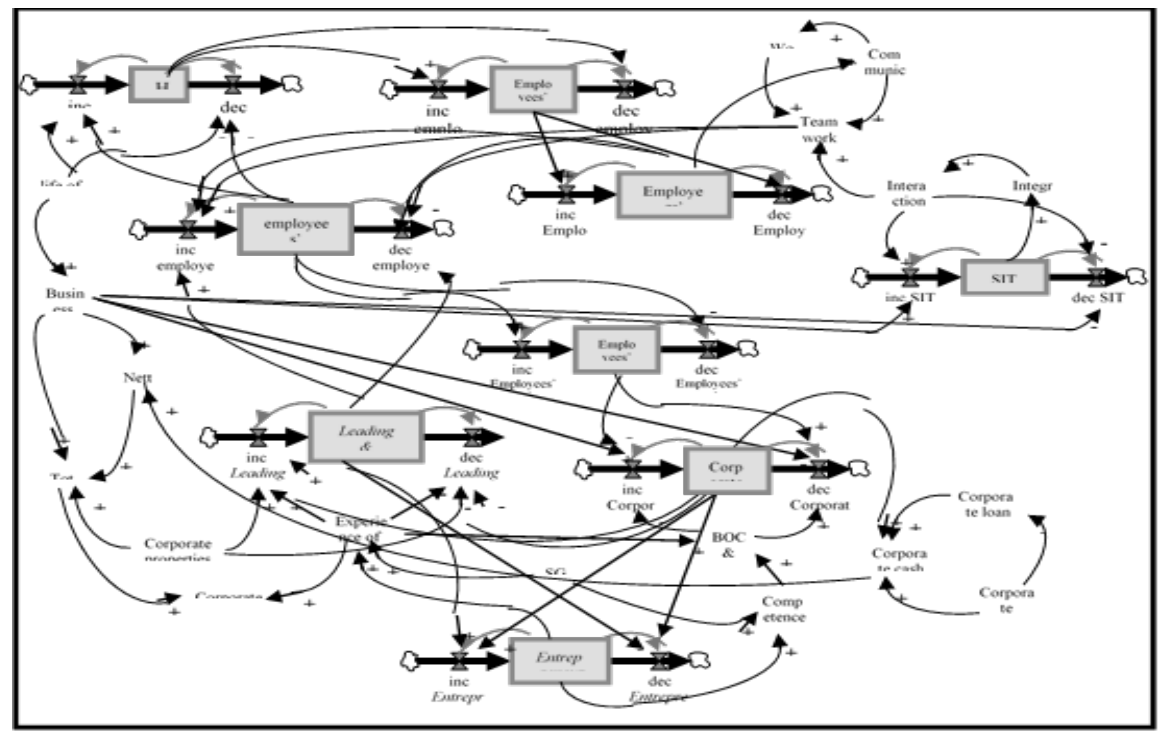

Source: processed data (2012) 
over time (to zero). Figure 6 shows the result of Riady's causal map by using the NUMBER method to obtain a model of system dynamics.

The company's Competitive Advantage is defined as the impact of the company's existence on people's lives. System dynamics model simulation results and the actual values (after transformation) for the variable of the Company's Competitive Advantage are shown in Table 3 and Figure 6 below.

Table 3.

The Simulation Results of the System Dynamics Model and the Actual Values (after Transformation) for the Company's Competitive Advantage

\begin{tabular}{cccc}
\hline Year & Simulation & $\begin{array}{c}\text { Simulation of } \\
\text { Increase } \\
\text { or Decrease (in } \\
\%)\end{array}$ & $\begin{array}{c}\text { Actual } \\
\text { values (after } \\
\text { transformation) }\end{array}$ \\
\hline 2002 & 0.2215 & & 0.2215 \\
2003 & 0.2236 & 0.91 & 0.2198 \\
2004 & 0.2351 & 5.16 & 0.2323 \\
2005 & 0.3042 & 29.41 & 0.2855 \\
2006 & 0.3853 & 26.64 & 0.4230 \\
2007 & 0.4589 & 19.11 & 0.5315 \\
2008 & 0.5346 & 16.50 & 0.4960 \\
2009 & 0.6076 & 13.65 & 0.5395 \\
2010 & 0.6803 & 11.96 & 0.6024 \\
2011 & 0.7445 & 9.44 & 0.6319 \\
\hline
\end{tabular}

Source: author-processed data (2012)

Figure 6.

The Simulation Results of the System Dynamics Model and the Actual Values (after Transformation) for the Company's Competitive Advantage

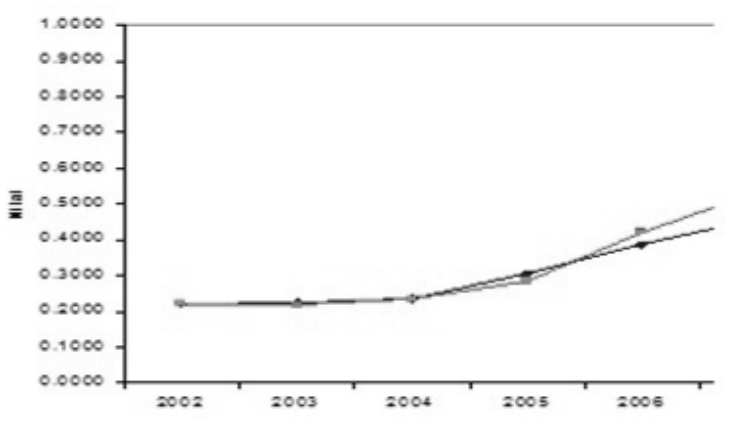

Source: author-processed data

\section{Company Profitability}

Company profitability is defined as the company's capability in acquiring annual profit. The simulation results of the system dynamics model and actual values (after transformation) for the company profitability variable are shown in Table 4 and Figure 8.

Table 4.

The simulation results of the system dynamics model and actual values (after transformation) for company profitability

\begin{tabular}{lccc}
\hline Year & Simulation & $\begin{array}{c}\text { Simulation of } \\
\text { increase or decrease } \\
\text { (in \%) }\end{array}$ & Actual \\
\hline $\mathbf{2 0 0 2}$ & 0.5123 & & $\mathbf{0 . 5 1 2 3}$ \\
$\mathbf{2 0 0 3}$ & 0.5762 & 12.48 & 0.5770 \\
$\mathbf{2 0 0 4}$ & 0.6299 & 9.32 & 0.6429 \\
$\mathbf{2 0 0 5}$ & 0.6752 & 7.19 & 0.6819 \\
$\mathbf{2 0 0 6}$ & 0.7131 & 5.61 & 0.6831 \\
$\mathbf{2 0 0 7}$ & 0.7444 & 4.39 & 0.6807 \\
$\mathbf{2 0 0 8}$ & 0.7695 & 3.37 & 0.6933 \\
$\mathbf{2 0 0 9}$ & 0.7889 & 2.52 & 0.7069 \\
$\mathbf{2 0 1 0}$ & 0.8031 & 1.81 & 0.7736 \\
$\mathbf{2 0 1 1}$ & 0.8129 & 1.22 & $\mathbf{0 . 8 1 2 5}$ \\
\hline
\end{tabular}

Source: research result (2012)

Figure 7.

The Simulation Results of the System Dynamics Model and Actual Values (After Transformation) for Company Profitability

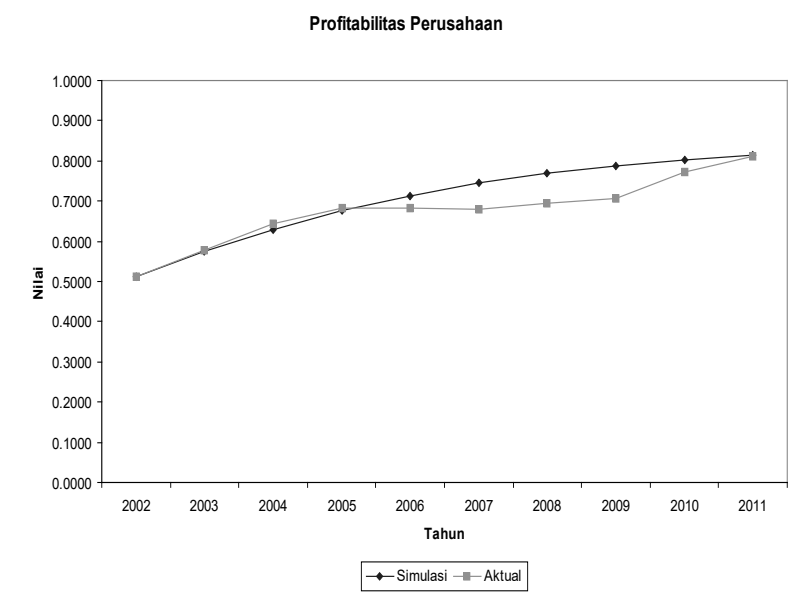

Source: research result (2012) 
Based on the simulation results shown in Figure 6-7, company profitability had experienced increase up to 2011.

$$
\left(\frac{0,8129-0,5123}{0,5123}\right) \cdot 100 \%=8, \theta \%
$$

However, based on a year to year observation, company profitability did not immediately increase, as it had climbed gradually instead.

Under actual conditions, company profitability had generally experienced an increase. Yet, from 2005 to 2009, this variable remained stable (relatively it neither increased nor decreased).

\section{Entrepreneur as a Business Leader}

Entrepreneur as a Business Leader is defined as the entrepreneur taking on the role as the leader of the company. The simulation results of the system dynamics model and actual values after transformation) for the Entrepreneur as a Business Leader variable are shown in Table 5 and Figure 8.

\section{Table 5.}

Simulation Results of the System Dynamics Model and Actual Values

(After Transformation) for Entrepreneur as a Business Leader

\begin{tabular}{cccc}
\hline Year & Simulation & $\begin{array}{c}\text { Simulation of } \\
\text { increase or decrease } \\
\text { (in \%) }\end{array}$ & Actual \\
\hline $\mathbf{2 0 0 2}$ & 0.5000 & & 0.5000 \\
$\mathbf{2 0 0 3}$ & 0.5167 & 3.33 & 0.5000 \\
$\mathbf{2 0 0 4}$ & 0.5419 & 4.87 & 0.5000 \\
$\mathbf{2 0 0 5}$ & 0.5750 & 6.12 & 0.5000 \\
$\mathbf{2 0 0 6}$ & 0.6299 & 9.53 & 0.7000 \\
$\mathbf{2 0 0 7}$ & 0.7010 & 11.29 & 0.7000 \\
$\mathbf{2 0 0 8}$ & 0.7750 & 10.57 & 0.7000 \\
$\mathbf{2 0 0 9}$ & 0.8430 & 8.77 & 0.9000 \\
$\mathbf{2 0 1 0}$ & 0.8978 & 6.51 & 0.9000 \\
$\mathbf{2 0 1 1}$ & 0.9377 & 4.44 & 0.9000 \\
\hline
\end{tabular}

Source: research result (2012)
Figure 8.

Simulation results of the system dynamics model and actual values

(After Transformation) for Entrepreneur as a Business Leader.

Cognitive Leadership

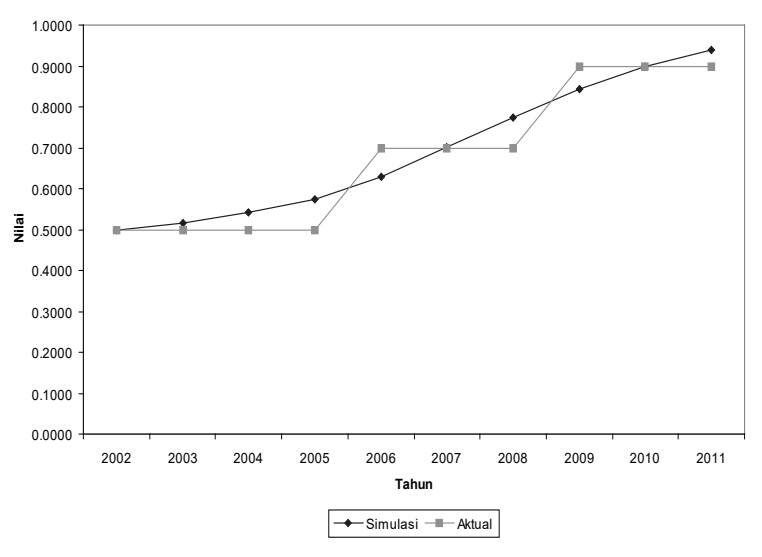

Source: research result (2012)

As shown in the simulation results in Figure 8, Entrepreneur as a Business Leader experienced a gradual rise year by year.

Under actual conditions, it is observed that Entrepreneur as a Business Leader tended to increase from one year to the next. Actual values are seen to fluctuate since actual values before transformation are discrete, i.e. 1, 2, 3, 4 , and 5 . The values are in discrete form $(1,2$, $3,4,5)$ because $1,2,3,4$, and 5 are defined in sequence as 1 = strongly disagree, $2=$ disagree, 3 $=$ slightly disagree, $4=$ agree, $5=$ strongly agree.

\section{Information and Technology System Implementation}

Information and Technology (IT) System Implementation refers to whether IT system in the company has been optimally implemented. The simulation results of the system dynamics model and actual values (after transformation) for the IT System implementation variable are shown in Table 7 and Figure 9. 
Table 7.

Simulation results of the system dynamics and actual values (after transformation) for IT system implementation.

\begin{tabular}{cccc}
\hline Year & Simulation & $\begin{array}{c}\text { Simulation of } \\
\text { increase or decrease } \\
\text { (in \%) }\end{array}$ & Actual \\
\hline $\mathbf{2 0 0 2}$ & 0.2500 & 19.06 & 0.2500 \\
$\mathbf{2 0 0 3}$ & 0.2977 & 18.13 & 0.2500 \\
$\mathbf{2 0 0 4}$ & 0.3516 & 18.44 & 0.2500 \\
$\mathbf{2 0 0 5}$ & 0.4164 & 18.41 & $\mathbf{0 . 2 5 0 0}$ \\
$\mathbf{2 0 0 6}$ & $\mathbf{0 . 4 9 3 1}$ & 19.29 & $\mathbf{0 . 7 5 0 0}$ \\
$\mathbf{2 0 0 7}$ & 0.5883 & 19.52 & 0.7500 \\
$\mathbf{2 0 0 8}$ & 0.7031 & 17.31 & 0.7500 \\
$\mathbf{2 0 0 9}$ & 0.8248 & 12.38 & 0.7500 \\
$\mathbf{2 0 1 0}$ & 0.9269 & 6.15 & 0.7500 \\
$\mathbf{2 0 1 1}$ & 0.9839 & & 0.7500 \\
\hline
\end{tabular}

Source: research result (2012)

The actual values for IT System Implementation variable level are seen to fluctuate since actual values before transformation have a discrete value of 0 and 1 , wherein 0 means IT system has not been optimally implemented, while 1 means IT system has been optimally implemented.
To clarify the presentation of values concerning IT System Implementation, the following variable level transformation equation is employed.

$$
\frac{x+0,5}{2}
$$

Based on simulation results shown in Figure 5.8, the value of IT system implementation variable sits at the $[0,1]$ interval. In 2006 the simulation value of the IT system implementation was close to 0.5 , or 0.4931 to be exact, it may thus be concluded that in 2006 the implementation of the IT system had begun to be discernable. This is also apparent under actual conditions, in which a value change had occurred, from 0.25 to 0.75 , indicating that the implementation of the IT system had been conducted optimally in that particular year.

\section{Human Resource}

Human Resource is defined as the number of full time employees working in the

Figure 9.

Simulation Results of the System Dynamics Model and Actual Values (After Transformation) for IT System Implementation

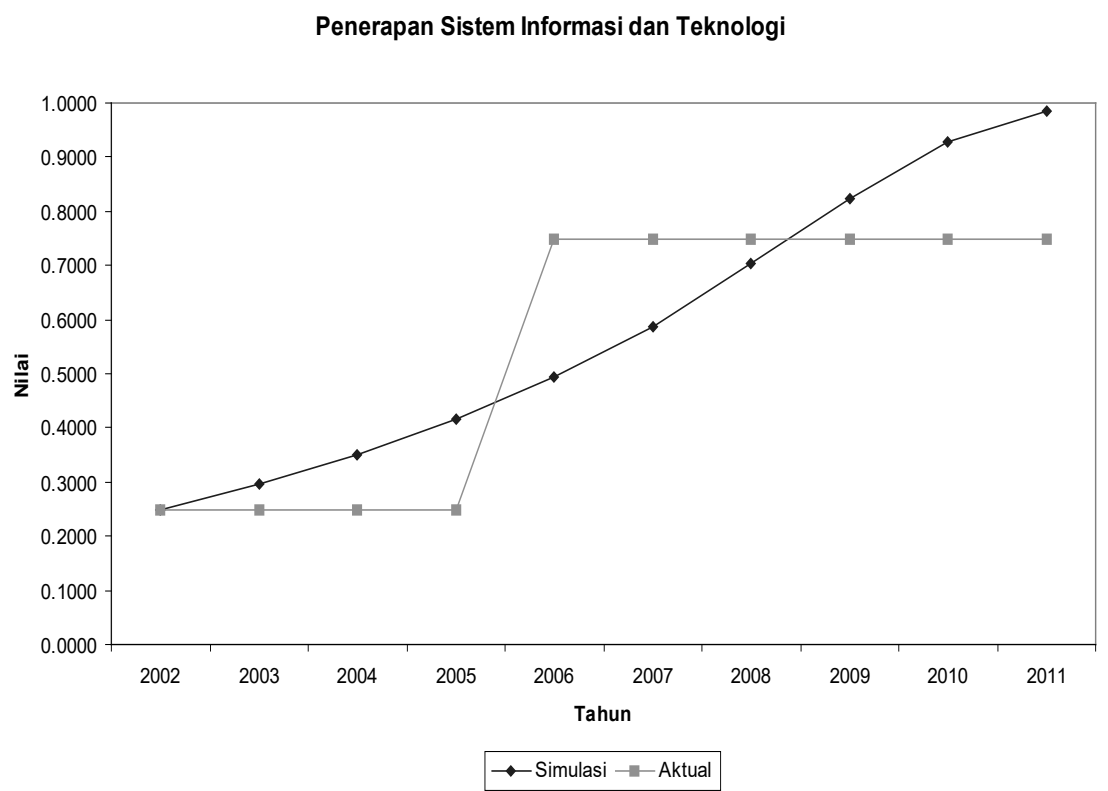

Source: research result (2012) 
company per annum. The simulation results of the system dynamics model and actual values (after transformation) for the Human Resource variable are shown in Table 8 and Figure 11.

Table 8.

Simulation Results of the System Dynamics Model and Actual Values

(After Transformation) for Human Resource

\begin{tabular}{lccc}
\hline Year & Simulation & $\begin{array}{c}\text { Simulation of } \\
\text { increase or decrease } \\
\text { (in \%) }\end{array}$ & Actual \\
\hline $\mathbf{2 0 0 2}$ & 0.4402 & & 0.4402 \\
$\mathbf{2 0 0 3}$ & 0.4524 & 2.76 & 0.4529 \\
$\mathbf{2 0 0 4}$ & 0.4641 & 2.59 & 0.4657 \\
$\mathbf{2 0 0 5}$ & 0.4779 & 2.98 & 0.4784 \\
$\mathbf{2 0 0 6}$ & 0.4941 & $\mathbf{3 . 3 8}$ & 0.5138 \\
$\mathbf{2 0 0 7}$ & 0.4941 & 0.00 & 0.5377 \\
$\mathbf{2 0 0 8}$ & 0.5450 & 10.30 & 0.5399 \\
$\mathbf{2 0 0 9}$ & 0.5814 & 6.69 & 0.5262 \\
$\mathbf{2 0 1 0}$ & 0.6242 & 7.37 & 0.5581 \\
$\mathbf{2 0 1 1}$ & 0.6718 & 7.62 & 0.5829 \\
\hline
\end{tabular}

Source: research result (2012)

Figure 10.

Simulation Results of the System Dynamics Model and Actual Values (After Transformation) for Human Resource

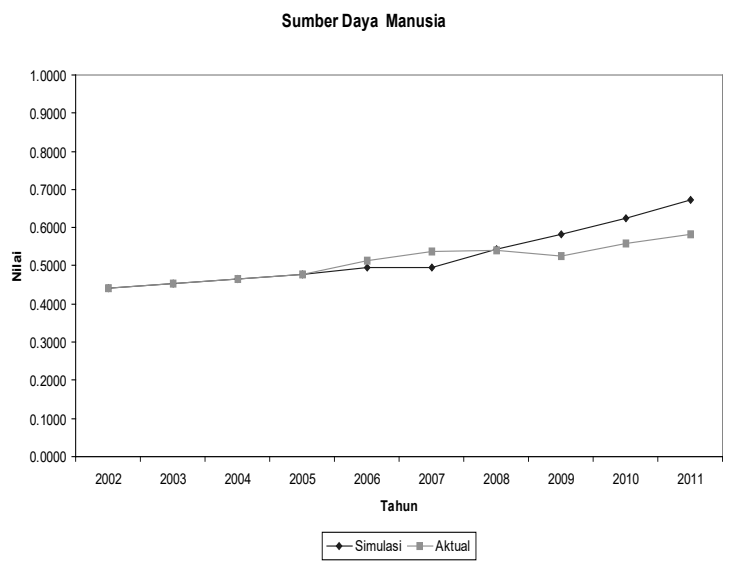

Source: research result (2012)

Based on simulation results in Figure 10, generally, the company's human resource had been increasing year by year up to 2011. The rise in human resource started to be seen in 2006 (with a 3.38\% increase). Yet in 2007, there was neither increase nor decrease in human resource $(0.00 \%)$, indicating that there was no full time employee recruitment at the company in that very year.

\section{Conclusion}

Based on the cognitive mapping as a business leader, there are four strategic directions that the corporation can apply, namely: human resource development, application of technology, financial management strategy, and entrepreneur as a business leader. The four strategic directions have become the benchmark in decisionmaking to create the company's competitive advantage, wherein competitive advantage is defined as the company's benefit for the society. The simulation results of the system dynamics show that from 2002 to 2011, the benefits provided by the corporation to the public had significantly increased in a consistent manner. This indicates that the company had seriously and consistently achieved its vision and mission to provide more values to the public.

This study implies that the strategic directions the founder had established have a long lasting impact in developing the corporation's competitive advantage. It can be said that most founders usually determine their long term goals in the corporation's vision statement. Strategic directions drawn in this cognitive map have their respective uniqueness based on the contextual level of the selected case. The cognitive map technique can be used for further research with other perspectives and simulated with other methods such as front end tool.

\section{References}

Ackerman, F., Eden, C. \& Cropper, S. (1992). Getting started with cognitive mapping. United Kingdom: University of Warwick. 
Alvarez, S. A. \& Busenitz, L. W. (2007). The entrepreneurship of resource based theory. Journal of Management, 27(2001), 755-775.

Annual Report of LPKR (Rep.). (2011).

Barney, J. B., \& Clark, D. N. (2007). Resource-based theory: creating and sustaining competitive advantage. Oxford: Oxford University Press.

Jensen, K. W., Håkonsson, D. D., Burton, R. M., \& Obel, B. (2009). Embedding virtually into organization design theory: virtuality and its information processing consequences. Information and Organization Design Series New Approaches to Organization Design, 99-119. doi: 10.1007/978-1-4419-0627-4_6

East Asia Analytical Unit - Dept. of Foreign Affairs and Trade of Australia. (1995). Overseas Chinese business network in Asia. Australia: Australian Government Pub. Service.

Giordano, C. B., \& Birkinshaw, J. (2007). The antecedents, consequences, and mediating role of organizational ambidexterity. Academy of Management Journal, 47(2), 209-226.

Hitt, M., Duane, R., Ireland, C., Michael, S., \& Sexton, D. (2002). Strategic entrepreneurship: creating a new mindset. Oxford, UK: Blackwell.

Hokky, S. (2004). Penggunaan fuzzy cognitive mapping dalam konstruksi analisis sosial (Working Paper). Bandung: Bandung Fe Institute.

Investor Summit and Capital Market Expo, September 28, 2011.

Jakarta Stock Exchange (JSX). Retrieved from http:// finance.detik.com. Wednesday, August 16, 2006.

Kim, D., H. (2000). A simulation method of cognitive maps. 1st International Conference on System Thinking in Management. Australia: Deakin University.
Kusumastuti, R. (2017). Innovation diagnostic of micro, small and medium enterprises (SME): A comparative study of innovation process of SME's in Depok and Solo. International Journal of Applied Business and Economic Research, 15(20).

Kusumastuti, R., Safitri, N, Firdaus, N., Styowati, M., \& Sakapurnama, E. (2016). Ambidexterity Learning Process for Exploration and Exploitation: A Model of Hybrid Ambidextrous University. Special Issue INTE(232).

Kusumastuti, R., Safitri, N., \& Khafian, Nidaan. (2015). Developing innovation capability through contextual ambidexterity. International Journal of Administrative and Organization, 22(1).

Marr., Schima., \& Neely (2004). Exploration and exploitation in organizational learning. Organization Science, 2(1), 71-87.

Perusich, K. (2010). Cognitive map. Vukovar: Intech.

Peteraf, M. (1993). The cornerstone of competitive advantage: a resource-based view. Strategic Management Journal, 14, 179-191.

Riady, M. (2008). Filsafat kuno dan manajemen modern. Jakarta: PT. Bhuana Ilmu Populer, Kelompok Gramedia.

Scheer, S. (2009). The entrepreneur as business leader: cognitive leadership in the firm. Cheltenham: Edward Elgar.

Smith, W. K., \& Tushman, M. L. (2005). Managing strategic contradictions: A top management model for managing innovation streams. Organization Science, 16(5), 522-536.

Ulengin F. \& Topcu Y.I. (1997). Cognitive mapKBDSS integration in transportation planning. Journal of the Operational Research Society, 48(11), 1065-1075. 